Article

\title{
Micro-resistance spot welding of cylindrical battery packets in FEM calculations
}

\author{
Zygmunt Mikno' ${ }^{1, *}$, Szymon Kowieski ${ }^{1}$ \\ ${ }^{1}$ Research Network ŁUKASIEWICZ - Welding Institute, Poland \\ Szymon Kowieski, M.Sc.; szymon.kowieski@is.gliwice.pl; \\ * Correspondence: Prof. Zygmunt Mikno; zygmunt.mikno@is.gliwice.pl
}

Received: 30.04.2019; Accepted: 29.07.2019

\begin{abstract}
Due to the increasing demand for connecting cells in packets to power electric tools, bicycles and electric cars, the issue of the quality of battery cells with busbars joints with the use of external heat electrodes is particularly important. The paper presents the conditions of the joining process and modelling results using the DC source. Modelling was performed using commercially available Sorpas 3D software. It included checking the influence of the busbar shape, clamping force, electrode material, the shape of electrode face, the length of the tungsten inserts in the welding electrodes on the amount of heat and the diameter of the connections. Modelling results revealed in particular increased heat generation and connection diameters for electrodes with a smaller work surface, however, industrial practice shows that the electrode face diameter durability is limited and that the electrodes flatten - the electrode face diameter increases.
\end{abstract}

Keywords: resistance spot welding of battery cells; micro-welding; battery cells compacting

\section{Introduction}

Cylindrical batteries combined into packets - accumulators, are increasingly used to power e.g. portable power tools, electric bikes, electric and hybrid cars. Batteries consist of a number of elements, and the basic element are cells connected in series or in parallel, enabling the achievement of the desired voltage and capacity. Other elements are the Battery Management System (BMS), busbars, cabling, shunts, wiring harnesses and housing [1,2].

Depending on the type of battery design, there are mainly pouch, prismatic and cylindrical batteries [2]. Due to the method of energy storage, lead-acid $(\mathrm{Pb})$, nickel-cadmium ( $\mathrm{NiCd})$, nickel-metal-hydride $(\mathrm{NiMH})$, sodium-nickel $\left(\mathrm{Na}-\mathrm{NiCl}_{2}\right.$ ) and the most commonly used lithium-ion (Li-Ion) batteries are distinguished [3,4], with at least four types of lithium-ion batteries [5:7]. Cylindrical lithium-ion batteries are commonly used in sets to power smaller power tool equipment, home installations (PowerWall) and electric cars.

Batteries are combined into sets usually using spot and projection resistance welding, ultrasonic and laser welding, less often by mechanical methods $[1,8]$. The quality of connections of each battery with the busbar affects the functioning and performance of the entire energy accumulation system. Connecting batteries is a challenge because of the need to combine often different materials with high electrical conductivity with a variable thickness combination $[9,10]$.

Resistance micro-welding is an effective way to reliably connect thin parts [11,12], such as $0.4 \mathrm{~mm}$ thick battery housings and $0.1 \mathrm{~mm}$ thick busbar [2]. Connecting elements, when compacting batteries into packages, is done by pressing the connected parts with the help of electrodes and the flow of electric current. Due to the specifics of the process of connecting finished elements (batteries), one of the ways of joining is one-sided resistance welding, where the electrodes are located on the connector side. Under the electrode pressure and during the welding current flow, heat is generated on the system resistances, which results in welding of the battery components $[12 \div 14]$.

An example of a battery after peel test of the connector with its visible parts on the battery housing is shown in figure 1a. Joint microscopic tests were performed to determine the quality of joints and reveal the microstructure of materials at the joint (Fig. 1b). 


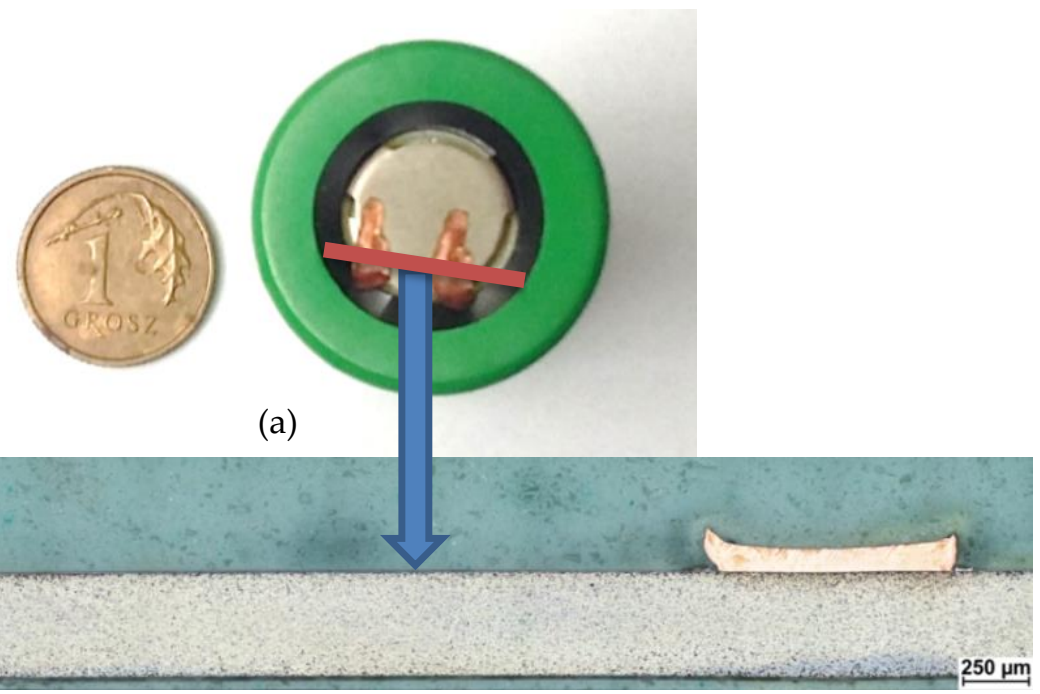

(b)

Fig. 1. Cylinder battery connection after peel test of a copper connector: a) general view, b) a microstructure covering both welds

In the metallographic image (Fig. 1b) a slight grain growth is noticeable for the steel sheet, which suggests that the temperature achieved in the steel sheet is in the range of $600 \div 700{ }^{\circ} \mathrm{C}$. The copper sheet surface from the contact side with the electrode has not been fused. The above allows to assume that the temperature did not exceed $900{ }^{\circ} \mathrm{C}$ [15]. In the numerical model, for the analysis of various variants, an isotherm of $800^{\circ} \mathrm{C}$ was adopted and this area was used to illustrate the size of the weld.

\section{Construction of the FEM model}

Finite element simulations were performed using the commercially available Sorpas 3D software (ver. 4.83) from Swantec. The view of the model is shown in figure 2. The simulations covered a number of elements, including steel sheet $0.4 \mathrm{~mm}$ thick, on which a $0.05 \mathrm{~mm}$ thick nickel coating was applied, a $0.05 \mathrm{~mm}$ thick copper connector was placed from above, pressed with tungsten electrodes $2 \mathrm{~mm}$ in diameter. An insulated flat support is used in the model from below. The electrodes, on the other hand, were pressed independently, each with a different adjustable pressure value for each of them. The model included direct current flow from one electrode to another in a one-sided welding system.

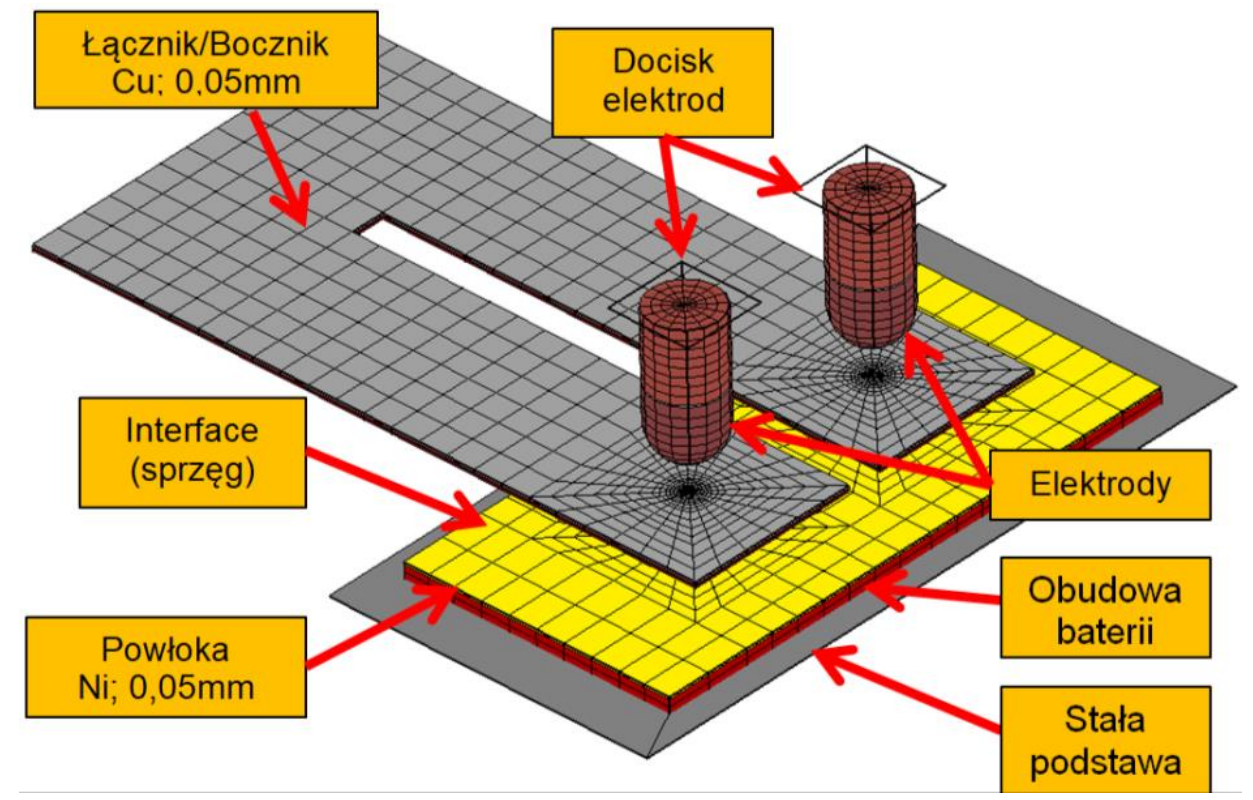

Fig. 2. FEM model of one-sided welding with two tungsten electrodes and a copper connector welded to the steel battery housing 
The Sorpas software has an open, embedded database of materials for various welded materials, especially for steels used e.g. in the automotive industry, but also materials used for electrodes. The developed models, depending on the geometry of the elements (e.g. length of tungsten electrodes, shape of the connector) had about 9400 elements. The model uses a DC source with a maximum welding current of $2.4 \mathrm{kA}$ (Fig. 3) and with a time of up-slope and down-slope of the current.

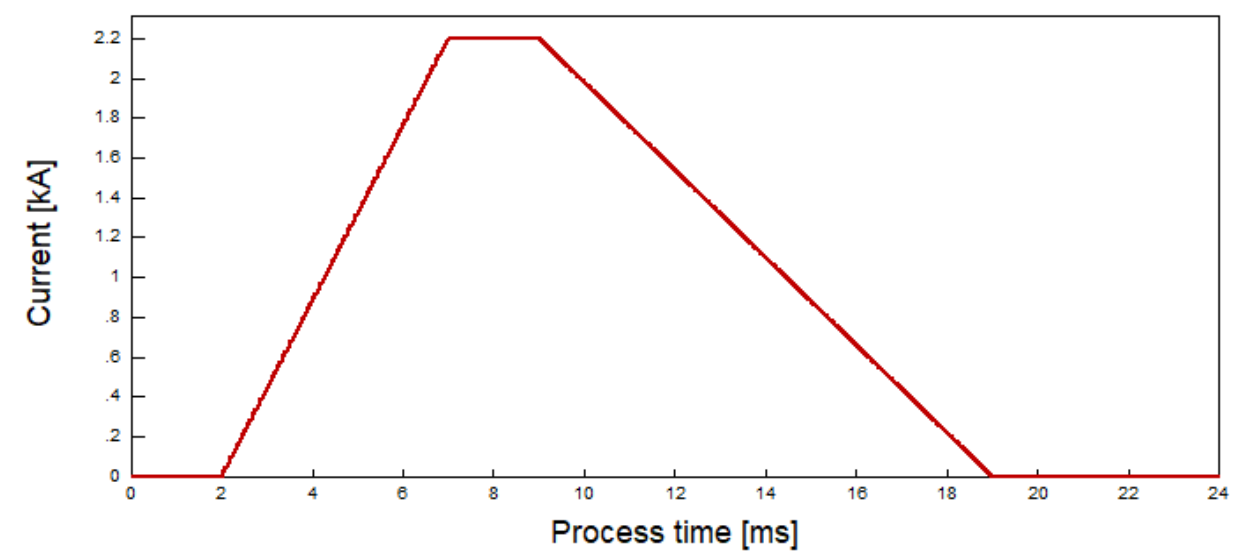

Fig. 3. Modelled course of the constant welding current: time of up-slope $-5 \mathrm{~ms}$; time of maximum welding current flow $-2 \mathrm{~ms}$, time of down-slope $-10 \mathrm{~ms}$

\section{FEM results}

Modeling with the use of Sorpas software allows presenting results among others in the form of temperature distribution in the welding area (Fig. 4), but also in the form of temperature waveforms or current density at selected points of the model's grid (Fig. 4) or electrode displacement. Modeling results are presented in table I and figures $5 \div 11$.

The tests included the effect of: welding current values, diameter of the flat surface of the electrodes working part, type of welding electrodes material, values of electrode downforce, active length (indentation) of the shunt (connector) and length of the electrodes on the temperature achieved in the welding area and on the quality of welded joints expressed by size of the weld diameter.

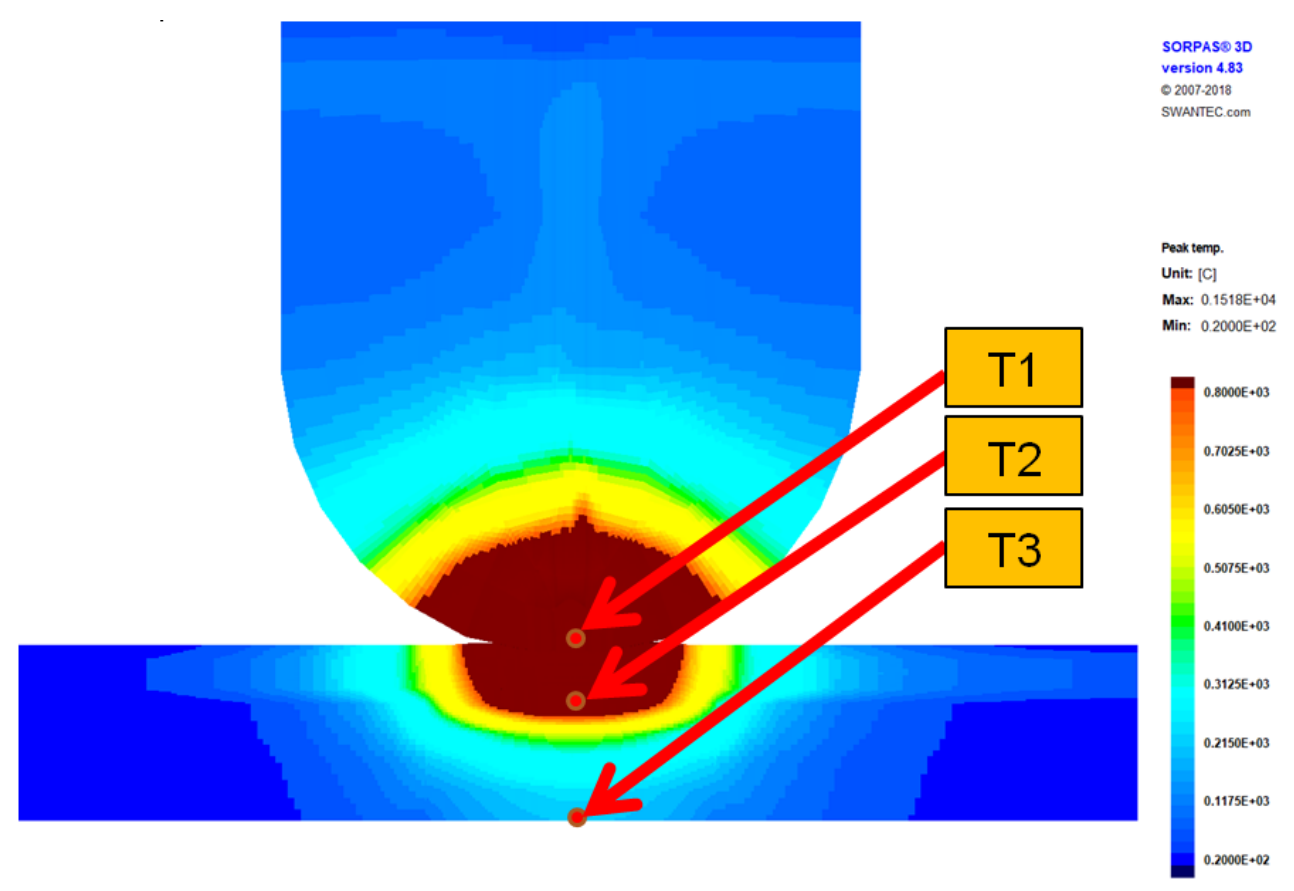

Fig. 4. Modelling results in the form of temperature distribution in the welding area. View of the cross-section through the connector with the burgundy colour marking of the area with a temp. above $800{ }^{\circ} \mathrm{C}$ : T1 - temperature at the electrode contact with the connector material; $\mathrm{T} 2$ - temperature in the contact of the connector with the battery housing; T3 - temperature of the battery housing from the inside 


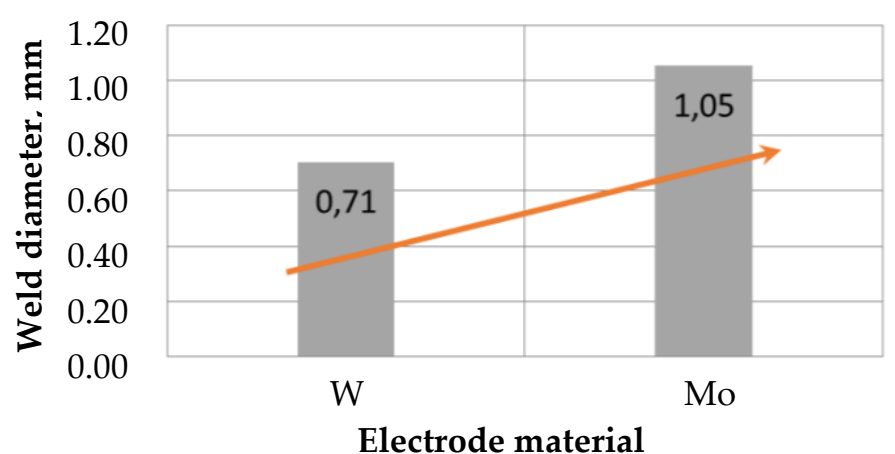

Fig. 5. The dependence of weld diameter on the electrode material (tungsten / molybdenum)

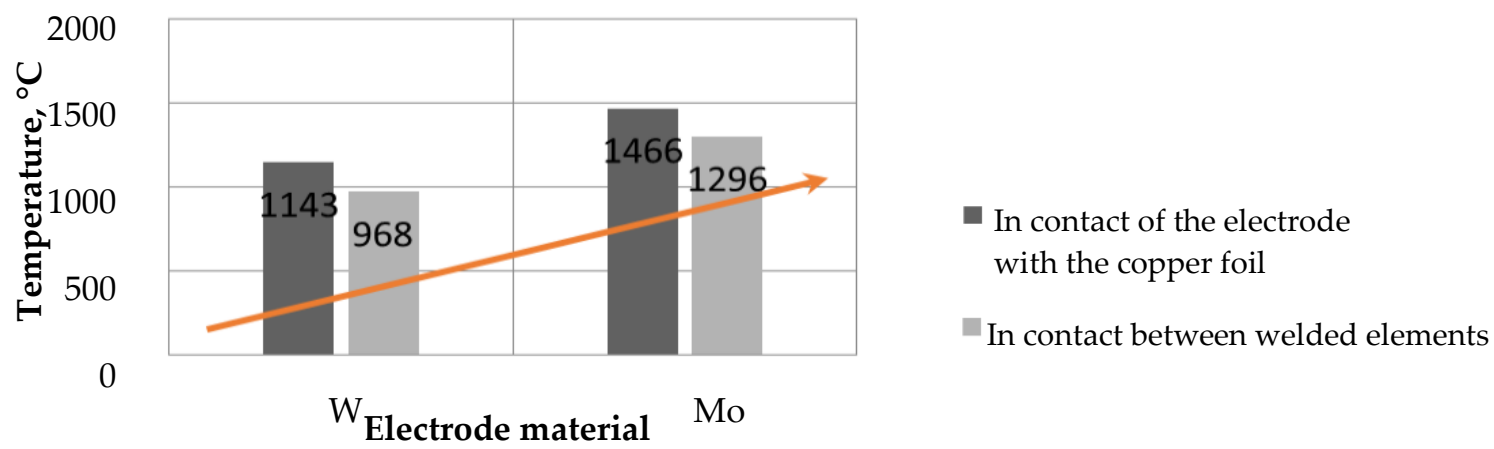

Fig. 6. Temperature dependence at selected points of the welding area from the electrode material

Table I. Parameters sets of the welding cycle and the results of MES modelling of the battery welding with a copper connector for various variants analysed

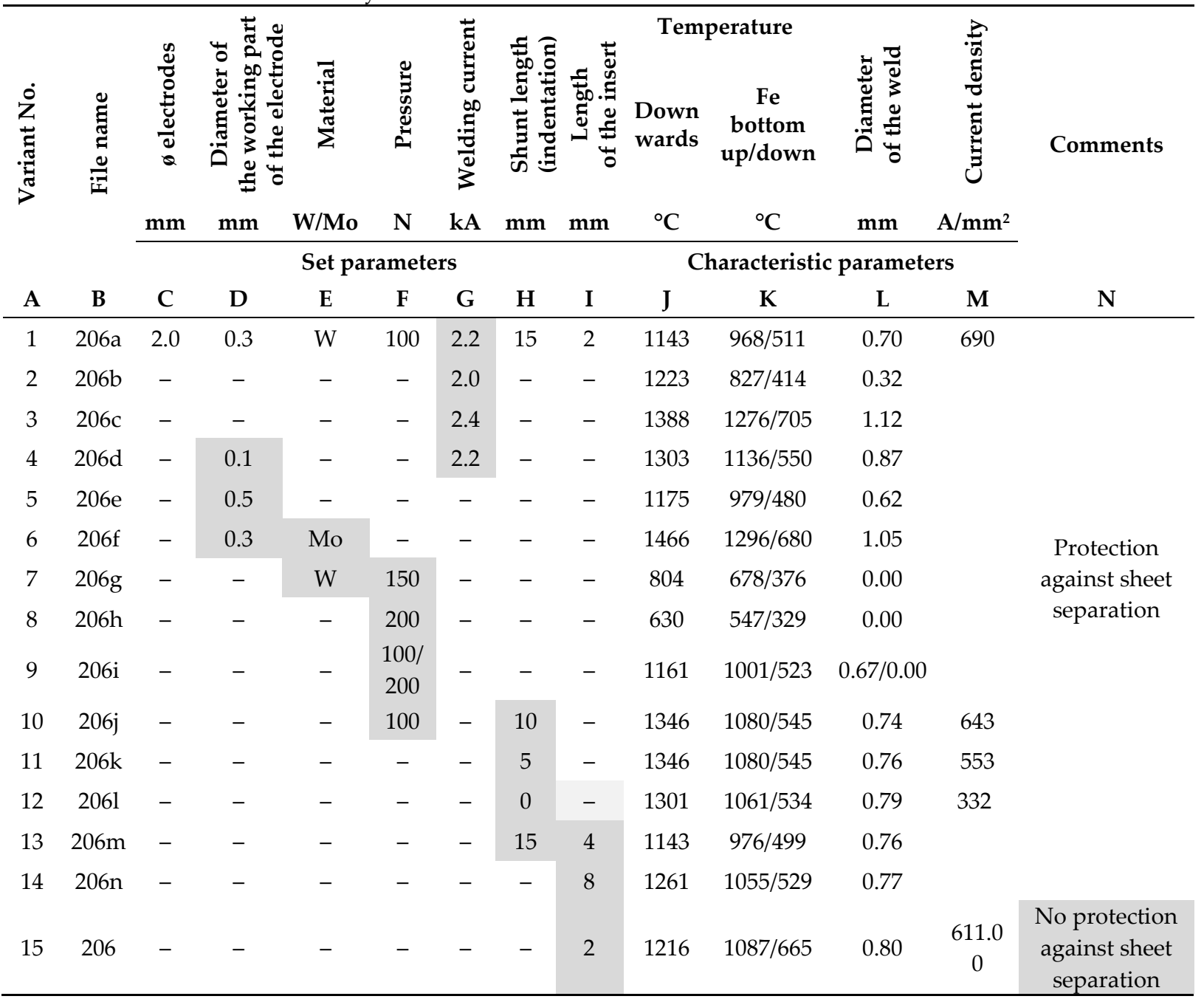




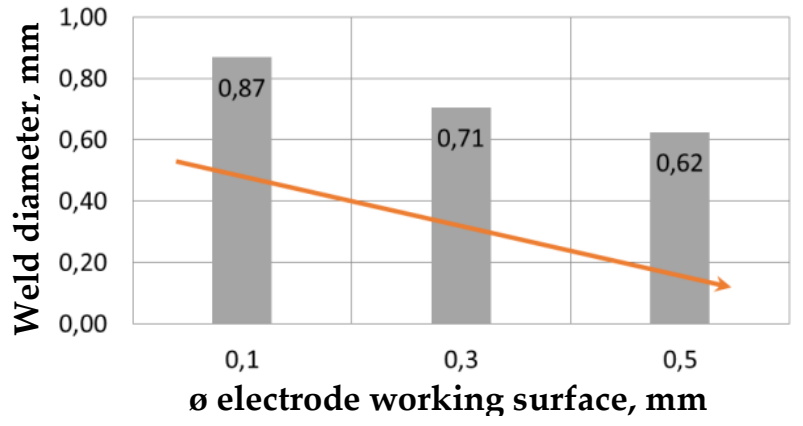

Fig. 7. The dependence of the weld diameter on the diameter of the electrode working surface

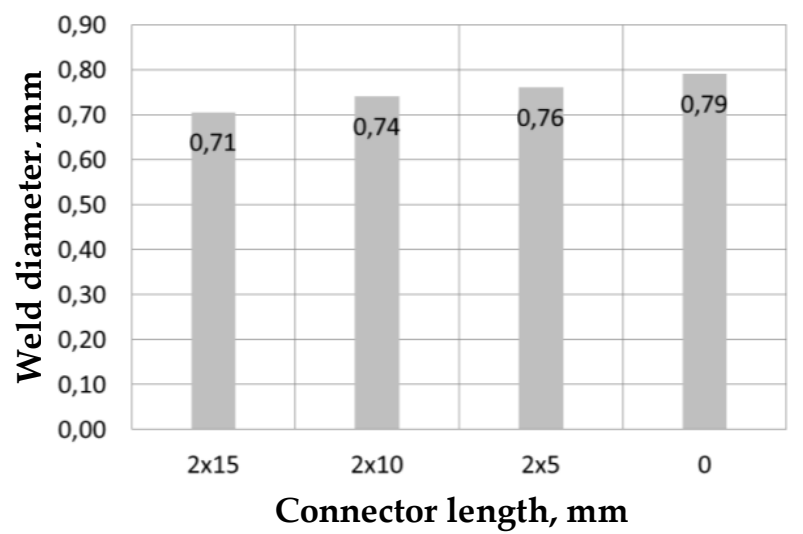

Fig. 8. The dependence of the weld diameter on the length of the connector



Electrode length, $\mathrm{mm}$

Fig. 9. The dependence of the weld diameter on the length of the tungsten insert and the temperature at selected points of the model

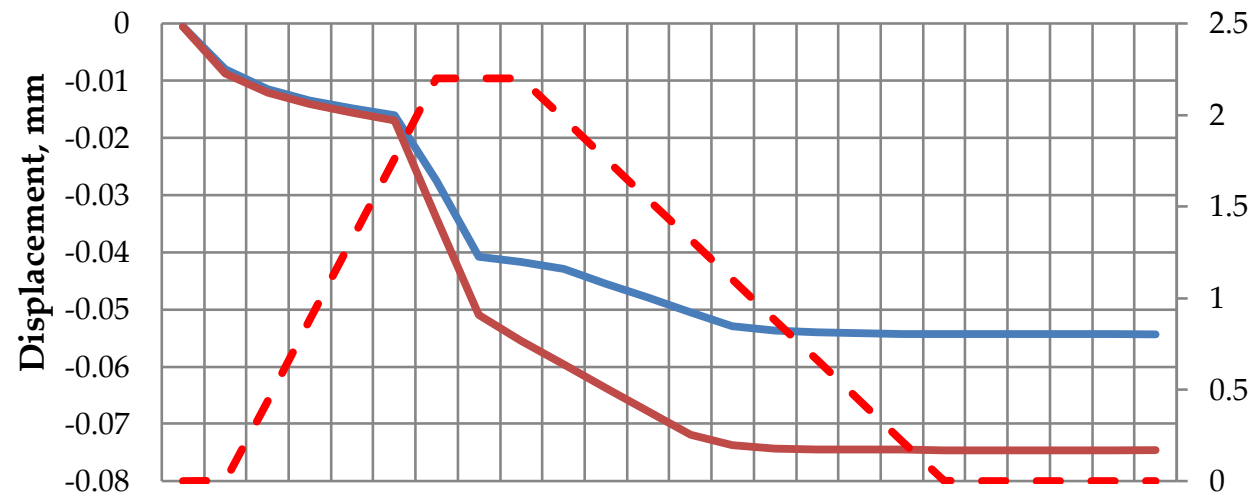

$\begin{array}{lllllllllllllll}1 & 2 & 3 & 4 & 5 & 6 & 7 & 8 & 9 & 1011 & 12 & 13 & 14 & 1516171819202122 & 2324\end{array}$

Process time, ms
2.5

5 志

Connector 2x15 mm Connector $0 \mathrm{~mm}$ - Welding current

Fig. 10. Displacement of electrodes during welding 


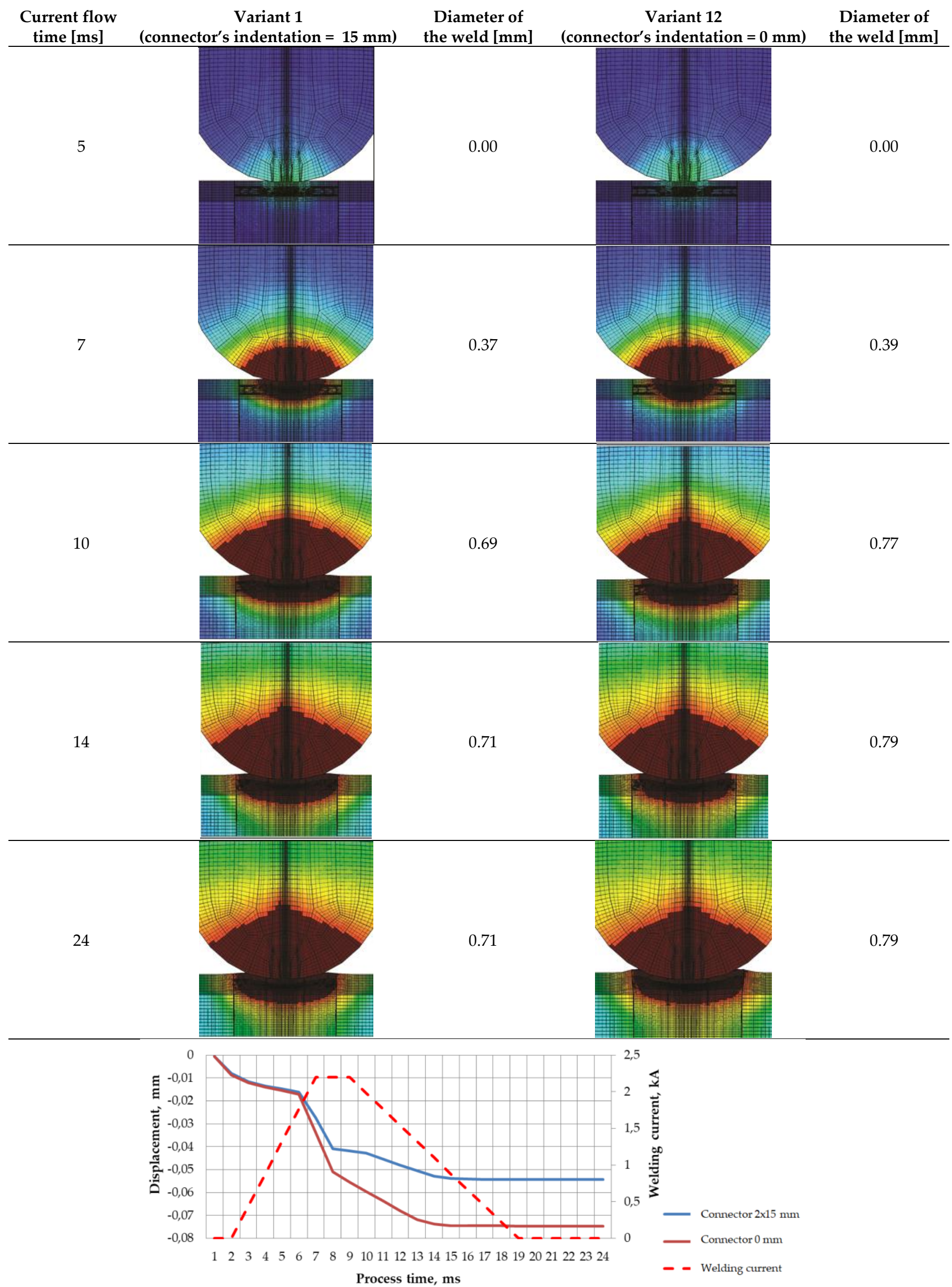

Fig. 11. Modeling results in the form of temperature distribution in the welding area with the marked area with a temperature above $800{ }^{\circ} \mathrm{C}$ (burgundy colour) and the displacement of electrodes for the selected current flow time for two lengths of the connector: $15 \mathrm{~mm}$ and $0 \mathrm{~mm}$ 


\section{Summary of numerical results}

The article analyzes the process of compacting the accumulator's battery set using resistance welding technology. The analysis was focused on connecting single cells of Li-Ion batteries with a voltage of $3.7 \mathrm{~V}$ and a capacity of $2100 \mathrm{mAh}$. One-sided resistance welding process was analyzed. A number of welding conditions and parameters were analyzed, including:

- welding current value (table I, lines $1 \div 3 ; \mathrm{I}=2.0 / 2.2 / 2.4 \mathrm{kA}$ );

- diameter of the flat surface of the working part of the electrodes (y) (Table I, lines 4 and $5 ; \mathrm{d}=0.1 / 0.3$ / $0.5 \mathrm{~mm}$ );

- type of material (tungsten / molybdenum) of welding electrodes (Table I, lines 1 and 6);

- value of the electrode downforce (Table I, lines $1,7 \div 9 ; \mathrm{F}=100 / 150 / 200 \mathrm{~N}$ );

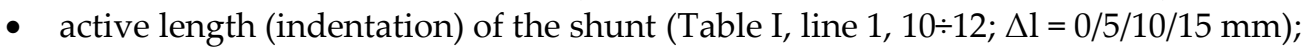

- electrode length (y) (Table I, lines $1,13,14 ; 1=2 / 4 / 8 \mathrm{~mm}$ ).

The comparisons were made in relation to option No. 1, considered as the reference option (parameters in Table I, line 1).

The design and material parameters of the battery cell and shunt were as follows:

- battery housing:

- material - steel;

- wall thickness $0.4 \mathrm{~mm}$;

- outer coating - nickel, thickness $0.05 \mathrm{~mm}$;

- Shunt:

- material - copper;

- thickness $0.1 \mathrm{~mm}$;

- distance between welding electrodes $-6 \mathrm{~mm}$;

- electrodes diameter $-2 \mathrm{~mm}$.

Table I summarizes the set parameters of the welding cycle (columns $C \div I$ ) and the characteristic parameters (columns $\mathrm{J} \div \mathrm{M}$ ). The characteristic parameters for the analysis were: $\mathrm{i}$ ) contact temperature of tungsten electrode - shunt (column J), ii) contact temperature of shunt - battery housing (column K), iii) temperature of the bottom surface of the housing (column K), current density determined on lower surface of the housing centrally between the electrodes (column M). The parameter for which the quality of the welded joint was determined was the weld diameter (column L).

Based on the numerical results in Table I and the graphic results in figures $5 \div 11$, the results were analyzed.

The parameters of table I (variant 1, line 1) were adopted as the reference conditions. The weld diameter obtained for these parameters is $\mathrm{d}=0.71 \mathrm{~mm}$. An area with a temperature above $800{ }^{\circ} \mathrm{C}$ was assumed as the diameter of the weld, which means that a solid-state joint was obtained. Total current flow time was $17 \mathrm{~ms}$, including $5 \mathrm{~ms}$ up-slope and $10 \mathrm{~ms}$ down-slope. The current waveform was mapped and appropriately approximated from the battery welding station of one of the manufacturing companies. The maximum value of current was $2.2 \mathrm{kA}$.

For a change in the current value in the range of $+/-10 \%$ from the maximum value, i.e. $2.0 / 2.4 \mathrm{kA}$, the weld diameter is reduced by $55 \%$ and increased by $60 \%$, respectively, obtaining a diameter of $0.32 \mathrm{~mm}$ (Table I, line 2) and $1.12 \mathrm{~mm}$ (Table I, line 3). Thus, a significant impact of the current value on the weld diameter is visible.

The analysis also indicates the effect of the flat working part of the electrode's surface on the diameter of the weld obtained. Due to the wear of the electrode (tungsten), the diameter of the flat working part was $0.3 \mathrm{~mm}$ as the reference condition. For the other diameter values analyzed, i.e. $0.1 \mathrm{~mm}$ and $0.5 \mathrm{~mm}$, an increase in weld diameter by approx. $24 \%(\mathrm{~d}=0.87 \mathrm{~mm}$ - Table I, line 4$)$ and a decrease in weld diameter by approx. $12 \%$ were observed, respectively $(\mathrm{d}=0.62 \mathrm{~mm}$ - Table $\mathrm{I}$, line 5$)$ - figure 5 .

The use of another material for the electrodes - molybdenum instead of tungsten, showed an increase in the weld diameter by $50 \%(\mathrm{~d}=1.05 \mathrm{~mm}$, Table I, line 6$)$ - figure 3. The increase in weld diameter is a desirable effect, but an increase of the temperature in the analyzed points of the model is a detrimental phenomenon. The temperature on the outer and inner wall of the battery reaches 1296 and $680{ }^{\circ} \mathrm{C}$, respectively (Table I, line 6, column J) and is the highest of all analyzed variants (Fig. 5 and Fig. 6).

The change of electrode downforce is one of the very important parameters of the welding cycle. This parameter has a large impact on the size of the weld diameter obtained. In the FEM calculations, the increased downforce was analyzed. For the force values of $150 \mathrm{~N}$ and $200 \mathrm{~N}$ a significant temperature drop was found 
in the analyzed welding area. The temperature did not exceed $800^{\circ} \mathrm{C}$, which according to the adopted criteria means zero value of the weld diameter.

An important aspect of battery compacting is the shape of the connector (shunt), which task is to limit the current flow through the shunt material and to force a larger current flow through the substrate material (battery housing). In the FEM analysis, the obtained weld diameter was assumed as the main criterion. The calculations analyzed various connector lengths from $2 \times 15 \mathrm{~mm}$ (15 mm indent) to zero (Table I, lines 1, $10 \div 12$ ). The results obtained are a bit of a surprise. Analyzing the diameter of the weld, a slight increase was found for cases of reducing the length of the connector. The weld diameter increased to approx. $14 \%$ for variant 12 (table I, line 12) for the zero value of the connector (Fig. 8). The observed effect results from the increased current flowing through the shunt material (between the electrodes), which causes its more intense heating in contact with the electrode. Figure 10 shows the displacement of the electrodes, which is clearly greater for the zero value of the connector. Higher current causes more intense heating and thus plasticizes the shunt material. Contrary to expectations (for a shunt made of copper and thickness of $0.1 \mathrm{~mm}$ ), reducing the length of the shunt's indentation does not bring the expected negative effects. The opposite effect is obtained in the form of an increased weld diameter. The effect of the weld diameter increases at selected moments of the current flow time for two variants with different shunt's indentation lengths, $15 \mathrm{~mm}$ (variant 1) and $0 \mathrm{~mm}$, respectively (variant 12) is shown in figure 11. For variant 12 , the effect of the weld diameter increase is observed, which, however, is associated with greater displacement of electrodes (dent).

The last parameter analyzed was the length of the electrode (tungsten). The results of FEM calculations have shown that as the electrode length increases, the weld diameter increases. For variant 14, i.e. electrode length $8 \mathrm{~mm}$, the weld diameter increased by $10 \%$. This is the result of heat dissipation by the tungsten electrode to the copper electrode holder. For longer tungsten electrode length, heat dissipation is less intense. Further increase in the electrode length (over $8 \mathrm{~mm}$ ) does not increase the weld diameter due to the stabilization of thermal conditions (supply and removal of heat to and from the welding area) in the analyzed model. However, it should be borne in mind that the calculation model assumes a constant current (maximum) value. This means that the assumed constant current value is stabilized and external conditions, e.g. in the form of a higher resistance in the current flow circuit, do not affect its change. From an electrotechnical point of view, the power source in the calculation model is a current source. An inverter welder with the option of stabilizing the welding current can be such a source. The energy source will behave differently based on the power supply from the capacitor, i.e. one in which the power source is a voltage source. For the latter case, an increase in resistance (greater length of tungsten electrodes) in the current flow circuit will result in a decrease in the welding current.

For better analysis and graphic presentation of results in the calculations (variants $1 \div 14$ ), so-called option "prevent separation" - protection against sheet separation, was used, which consisted in the lack of deformation of the elements consisting in the phenomenon of an opening between the joined elements. Variant 15 unchecked this option. The results obtained for variant 15 differ in the range of about $10 \%$ from the reference option. This effect will be taken into account in future studies.

\section{Conclusions}

For the case of compacting the battery, using one-sided resistance welding, various variants were analyzed numerically, i.e. the impact of welding cycle parameters and technological parameters. Analysis of the results allowed for the formulation of several of the following important conclusions:

1. The shape of the working part of the electrode has a significant impact on the size of the weld diameter. To maintain process repeatability, prepare electrodes with a flat working diameter $(0.3 \mathrm{~mm})$. Increasing this parameter during welding, as a result of electrode wear, will cause a significant decrease in the weld diameter.

2. For the various electrode materials analyzed, i.e. tungsten and molybdenum, an increase in the weld diameter for the molybdenum electrode was found. The temperatures obtained in the analyzed points were higher by approx. $30 \%$ compared to the tungsten electrode, which may be unfavorable from the point of view of the reaction of the medium (agent) filling the battery. If molybdenum is used as electrode material (instead of tungsten), the welding cycle current parameters should be reduced.

3. The increase of the downforce has a very strong and at the same time significant impact on the reduction of the weld diameter. A $50 \%$ increase in downforce results in no welds at all. Its total disappearance is observed for the assumed $800{ }^{\circ} \mathrm{C}$ isotherm. 
4. In the analyzed case of a shunt made of copper with a thickness of $0.1 \mathrm{~mm}$, an unexpected effect was found in the form of an increase in the weld diameter when the shunt length (indentation) was reduced. The obtained results can be explained by greater heating and thus plasticization of the shunt material, which is confirmed by the larger indentation of the electrodes in the welded material.

Due to the use of batteries in electromobility, future research will include different shunt materials and thicknesses.

Conflicts of Interest: The authors declare no conflict of interest.

\section{References}

[1] Lee S.S., et al., Joining technologies for automotive lithium-ion battery manufacturing: A review, Proceedings of the ASME 2010 International Manufacturing Science and Engineering Conference, 2010, Vol. 1, 541-549. [CrossRef]

[2] JMBS, Our Guide to Batteries; Johnson Matthey Battery Systems: Milton Keynes, UK, 2015.

[3] Kiehne H.A., Battery technology handbook, CRC Press, 2003. [Hyperlink]

[4] Besenhard J.O. (ed.), Handbook of battery materials, John Wiley \& Sons, 2008. [Hyperlink]

[5] Cao J., Emadi A., A new battery/ultracapacitor hybrid energy storage system for electric, hybrid, and plug-in hybrid electric vehicles, IEEE Transactions on power electronics, 2012, Vol. 27(1), 122-132. [Hyperlink]

DOI: 10.1109/TPEL.2011.2151206

[6] Yan D. et al., Comparing the performances of different energy storage cells for hybrid electric vehicle, EVS28 International Electric Vehicle Symposium and Exhibition, 2015, Goyang, Korea. [Hyperlink]

[7] Kras B., Gutkowski R., Figura R., Rodzina modułowych baterii litowych w technologii LTO z systemem zarządzania termicznego do pracy $\mathrm{w}$ systemach autobusowych szybkiego ładowania, Autobusy: technika, eksploatacja, systemy transportowe, 2016, Vol. 17(12), 1088-1091.

[8] Li H., et al., Transient temperature and heat flux measurement in ultrasonic joining of battery tabs using thin-film microsensors, Journal of Manufacturing Science and Engineering, 2013, Vol. 135(5). [CrossRef]

[9] Baranowski M., Kondej A., Zgrzewanie rezystancyjne cienkich elementów oraz mikrozgrzewanie, Przeglad Mechaniczny, 2014, No. 9, 44-48. [Hyperlink]

[10] Kang B., Cai W., Tan C.-A., Dynamic response of battery tabs under ultrasonic welding, Journal of Manufacturing Science and Engineering, 2013, Vol. 135(5).

[11] Alexy M. van de Wall D., Geoff S., Boyle L. M. et al., Akumulatory wymagają trwałych połączeń - czy zgrzewanie rezystancyjne, spawanie metodą TIG i spawanie laserowe to najlepsze technologie łączenia? Biuletyn Instytutu Spawalnictwa, 2019, vol. 91(1), 52-59. [CrossRef]

[12] Brand M.J. et al., Welding techniques for battery cells and resulting electrical contact resistances, Journal of Energy Storage 2015, Vol. 1, 7-14. [CrossRef]

[13] Gnyusov S.F., et al. Formation of a joint in resistance spot microwelding, Welding International, 2005, Vol. 19(9), 737-741. [CrossRef]

[14] Zhang H., Senkara J., Resistance welding: fundamentals and applications, CRC press, 2011. [CrossRef]

[15] Ocena metalograficzna połączenia miedź - stal - dr inż. Andrzej Winiowski prof. Instytutu Spawalnictwa.

(C) 2019 by the authors. Submitted for possible open access publication under the terms and conditions of the Creative Commons Attribution (CC BY) license (http://creativecommons.org/licenses/by/4.0/). 